\title{
PRESENCE OF ESCHERICHIA COLI IN URFA CHEESE AND IN VITRO SCREENING OF DONKEY MILK AND ESSENTIAL OIL OF MICROMERIA CONGESTA FOR ANTIBACTERIAL ACTIVITY USING DISC DIFFUSION METHOD*
}

\author{
Hikmet DINÇ ${ }^{1}$, Serap KILIÇ ALTUN² \\ ${ }^{1}$ Department of Pharmacology and Toxicology, Faculty of Veterinary Medicine, Harran University, \\ Şanliurfa,63200, Turkey \\ ${ }^{2}$ Department of Food Hygiene and Technology, Faculty of Veterinary Medicine, Harran University, \\ Şanlıurfa, 63200, Turkey
}

Geliş Tarihi: 08.12.2017 Kabul Tarihi: 18.12.2017

Makale Kodu: 363970

*This paper was presented at the International Conference on Agriculture, Forest, Food Sciences and Technologies (ICAFOF) which took place on May 15-17, 2017, in Cappadocia /Turkey

\begin{abstract}
The aim of this study was to determine the presence and antibiotic resistance profile of Escherichia coli strains in Urfa cheeses and comparing the antibacterial activity of donkey milk and essential oil of Micromeria congesta plant. For this purpose, 93 fresh Urfa cheese samples were obtained in Şanllurfa province. Bacteria were isolated and identified by conventional cultural technique. In vitro susceptibility test for antibiotics, donkey milk and essential oil of Micromeria congesta were performed with KirbyBauer disc diffusion method. Steam distillation was used to provide the essential oil of Micromeria congesta. E.coli strains were isolated in 43 (46\%) of all cheese samples. The E.coli were highly resistant to clindamycin $(100 \%)$, penicillin $(100 \%)$, oxacillin $(100 \%)$, tetracycline $(100 \%)$, neomycin $(80 \%)$, kanamycin (80\%), gentamycin (50\%), enrofloxacin (50\%), streptomycin (46\%) and low level of resistance to imipenem (20\%), cefoxitin (16\%). This study showed E.coli strains developed high rates of multidrug resistance. Antibacterial activity of Micromeria congesta essential oil and donkey milk was found to be more effective when compared to reference antibiotics (tetracycline and streptomycin).
\end{abstract}

Keywords: Urfa cheese, donkey milk, Micromeria congesta, antibacterial activity

İletişim / Correspondence

Department of Food Hygiene and Technology, Faculty of Veterinary Medicine, Harran University, Eyyübiye

Campus, Şanlıurfa, 63200, Turkey.

85 +904143183941

$>$ skilicaltun@harran.edu.tr 


\section{URFA PEYNIRLERINDE ESCHERICHIA COLI'NIN VARLIĞI VE EŞEK SÜTÜ VE MICROMERIA CONGESTA ESANSIYYEL YAĞININ ANTIBBAKTERIYYEL AKTIVITTESININ DISK DİFÜZYON YÖNTEMIYLE IN VITRO GÖRÜNTÜLENMESI}

\section{ÖZET}

Bu çalışmanın amacı, Urfa peynirlerinde Escherichia coli suşlarının varlığını ve antibiyotik direnç profilini belirlemek, eşek sütü ve Micromeria congesta bitkisi esansiyel yağının antibakteriyel etkinliğini karşılaştırmaktır. Çalışma kapsamında, Şanlıurfa ilinden 93 adet taze Urfa peyniri örneği toplandı. Konvansiyonel kültür tekniği ile izolasyon ve identifikasyon gerçekleştirildi. Kirby-Bauer disk difüzyon yöntemi ile antibiyotik, eşek sütü ve Micromeria congesta uçucu yağı için in vitro duyarlılık testi yapıldı. Micromeria congesta'nın uçucu yağını elde etmek için buhar distilasyon yöntemi kullanıldı. Tüm peynir örneklerinin 43'ünde (\% 46) E. coli suşu izole edildi. E. coli suşları, klindamisin (\% 100), penisilin (\% 100), oksasilin (\% $100)$, tetrasiklin (\% 100), neomisin (\% 80), kanamisin (\% 80), gentamisin (\% 50) enrofloksasin (\% 50), streptomisin (\% 46)'e yüksek direnç; imipenem (\% 20), sefoksitin (\% 16)'ine de düşük direnç gösterdi. Bu çalışma $E$. coli suşlarının yüksek oranda çoklu ilaç direnci geliştirdiğini gösterdi. Micromeria congesta esansiyel yağı ve eşek sütünün antibakteriyel etkinliği referans antibiyotikler (tetrasiklin ve streptomisin) ile kıyaslandığında antibakteriyel etkinliğinin daha etkin olduğu görüldü.

Anahtar kelimler: Urfa peyniri, eşek sütü, Micromeria congesta, antibakterial aktivite

\section{INTRODUCTION}

Milk and dairy products are essential nutrients for the development of the human body. Cheese is a balanced dairy product containing fats, proteins, minerals and most of the required daily vitamins. In addition, it is the most widely consumed dairy product worldwide (1). Milk is comprised of very low levels of microorganisms when milked from healthy animals. On the other hand, many microorganisms such as Escherichia coli, can be found in containers used during activities such as milking, distribution and transportation, and from animal's skin, barn's air or milker. In order to minimize the contamination risk, milk should be cooled and transferred to the manufacturing facility immediately. In Şanliurfa, Urfa cheeses produced with traditional methods from raw milk, that are generally milked in non-hygienic conditions and not subjected to cooling process, may consti- tute a potential risk for human health (2).

Feces of cows are important reservoir, thus, the milk obtained from these cows are more likely to have E. coli contamination (3). E. coli, a member of the Enterobacteriaceae family, is a gram-negative bacterium and found in the intestinal flora of human beings and animals, in water, plants, and soil (4). Since it is originated from the intestinal flora, its presence in food, indicates a fecal contamination (5). Pathogenic E. coli strains have been reported to cause meningitis, septicemia, food poisoning, intestinal and urinary tract diseases, which is also the second most important cause of mastitis disease seen in high milk yielding cattle $(6,7)$.

For the prevention or the treatment of mastitis, selection of inappropriate antibacterial drugs and their insufficient or high dose usage generates antibiotic resistant $E$. coli strains (8). This type of resistance is called 
as acquired resistance. It has been reported that with the transfer of the induced acquired antibacterial resistance and virulence factors to another bacterium by conjugation leads to an increase in the number of resistant strains $(9,10,11)$. Moreover, the resistance bacteria display due its innate structure is defined as intrinsic resistance. Essentially, E. coli produce broad-spectrum beta-lactamase (ESBL) enzymes. Therefore, by breaking the beta-lactam ring with these enzymes, they eliminate the beta-lactam antibiotics $(5,12)$. Antibiotic resistance is encountered in bacteria against all antibiotics used in clinics for human or animal health (9). Furthermore, antibacterial resistance is not only a national problem that concerns the present, but also a critical international issue that can negatively affect the whole world in the future (12). Hence, precedence should be given to testing for resistance against commonly used antibiotics such as penicillin, erythromycin, amoxicillin-clavulanic acid, neomycin, gentamycin, cephalosporins, ampicillin, lincomycin and spiramycin applied to the udder during the milking period. For that purpose, antibiograms should be performed to E. coli isolated from foods of animal origin all over our country, and drugs that are more effective on the bacteria should be detected $(13,14)$. One of the most common methods for antibacterial resistance detection is the Bauer-Kirby Disk diffusion method (15).

Due to the resistance problem in our country and in the world, many studies on herbal and animal originated materials, that can be alternatives to semisynthetic and synthetic antibacterial drugs, are being conducted. In vivo and in vitro studies showed that plants carry topical antibacterial effects (8). It has been reported that the antibacterial effect of essential oils of the Micromeria congesta (M. congesta) plant is close to that of synthe- tic antibiotics (16). M. congesta is a member of Micromeria genus that belongs to Labiatae family which have 22 taxa and have naturally grown in Turkey (16). M. congesta is an endemic plant which is generally named "punge tehta" and "gihaye palug" (17) The plant is often used as a folkloric medicinal treatment against headache, cough, and pulmonary infections (18). In a study, the total bacterial burden in donkey milk was found to be lower than in cow milk, and it was demonstrated that this decrease was due to the natural antibacterial components of donkey milk such as the lactose and lysozyme enzymes (19).

In this study, it was aimed to isolate E.coli strains in Urfa cheese produced by traditional methods in Şanlıurfa, to determine the resistance levels of commonly used antibiotics by antibiogram test, and to investigate the antibacterial effects of donkey milk and the essential oils of the $M$. congesta plant, which are potential alternatives to antibacterial medicine in the therapy of infectious diseases, on the E. coli strains.

\section{MATERIAL AND METHODS}

In this study, 93 fresh Urfa cheese samples were obtained from local markets in Şanluurfa province between January to March 2017. Samples were collected under aseptic conditions as $250 \mathrm{~g}$ each. They were brought to the Department of Food Hygiene and Technologies laboratories of Veterinary Faculty of Harran University in cold chain, and stored at -20 0C until analyze.

Samples were portioned as $25 \mathrm{~g}$ each under sterile conditions and were transferred to sterile stomacher bags with an addition of $225 \mathrm{~mL}$ of modified Tryptic Soy Broth (mTSB with novobiocin; Merck, Germany) After homogenization samples were incubated for 12 hours at $41^{\circ} \mathrm{C}$ under aerobic conditions. Chromocult TBX Agar (Merck, Darmstadt, Germany) was used for isolation. 
Then the immunomagnetic separation (IMS) method was used according to the manufacturer's instructions (Dynabeads, Inc., Dynal, Norway). Five typical colonies from petri dishes used for identification. Antibiotic susceptibility tests were done by the disc diffusion method as described Bauer et al. (20) with Mueller Hinton agar (Oxoid, UK). Zones of inhibition were measured after 24 hours and again after 48 hours of incubation at $37^{\circ} \mathrm{C}$. A suspension of the tested microorganism $(0.1$ $\mathrm{mL}$ of 108 cell $\mathrm{s} / \mathrm{mL}$ ) was spread on media plates. Sterilized discs of $6 \mathrm{~mm}$ (Schleicher and Schuell, No. 2668) were soaked with $0.25 \mu \mathrm{L}$ of oil and donkey milk placed on the inoculated plates and after staying at $4^{\circ} \mathrm{C}$ for 2 hours were incubated at $37^{\circ} \mathrm{C}$ for 24 hours. The diameters of the inhibition zones were measured in millimeters.

$M$. congesta were gathered during the flowering season in June to July 2016, from the Germüş village of Şanlıurfa. Dr. Mustafa Aslan identified all the gathered plants as M. congesta. The plants were collected in polyethylene bags. The essential oil of $M$. congesta was provided via hydrodistillation by using a Clevenger type apparatus for 6-8 hours. The essential oil samples were dehydrated by hydrous sodium sulfate and kept at + $4{ }^{\circ} \mathrm{C}$ until analysis (16).

\section{RESULTS}

In this study 93 Urfa cheese samples were analyzed for the presence of E. coli by using the conventional culturing method. All $E$. coli isolates gave Gram-negative, oxidase, and sorbitol negative and catalase positive reactions.

E. coli strains were isolated in 43 (46\%) of all cheese samples. E. coli strains were highly resistant to clindamycin (100\%), penicillin $(100 \%)$, oxacillin $(100 \%)$, tetracycline $(100 \%)$, neomycin $(80 \%)$, kanamycin (80 $\%$ ), gentamycin (50\%), enrofloxacin (50\%), streptomycin (46\%) and low level of resistance to imipenem (20\%), cefoxitin (16\%). In vitro, antibiotic sensitivity test was done as per recommendation of the Clinical and Laboratory Standard Institute (21).

\section{DISCUSSION}

Food chain has been known as one of the primary passage for antibiotic-resistant bacteria between the animal and human population is an accepted opinion (5).

E. coli is a fecal contamination indicator in foods and classified into subtypes which groups of strains cause diseases that have different virulence factors (22). The most clinical syndromes in humans are hemorrhagic colitis and hemolytic uremic syndrome (23). Dairy products produced using raw milk contaminated with $E$. coli could be risk to human health, by the bacteria may survive throughout the producing and ripening process of dairy products. The ability of E. coli is noted with different kind of traditional dairy products which are made from raw cow milk (24), raw goat milk lactic cheeses (23), yogurt (25), and, moreover Feta cheese (26) has been reported. Previous studies have been reported the antibiotic resistance in E.coli strains isolated from milk and dairy products and the described antibacterial resistance levels appear material-specific without the main attitude $(27,28)$. All E. coli isolates were found to be resistant to tetracycline and clindamycin which are also used in practice to treat coliform infections (24). Dinç et al.(2012) reported that among the E. coli strains which were isolated from milk samples in Ankara, Balıkesir, and Çorum, the highest resistance rates were analyzed against to erythromycin, ampicillin, tetracycline, nalidixic acid, chloramphenicol, trimethoprim-sulfamethoxazole and amoxicillin-clavulanic acid, respectively (8). In this study multidrug resistance of $E$. coli was detected on two or more antibiotics such as 
Table 1: Percentage antibiotic resistance of $E$. coli isolates from Urfa cheese samples

\begin{tabular}{|c|c|c|c|c|}
\hline Antibiotics & $\mathrm{n}$ & $\mathrm{R}$ & I & $\mathrm{S}$ \\
\hline Streptomycin $(10 \mu \mathrm{g})$ & 24 & $11(46 \%)$ & $11(46 \%)$ & $2(8 \%)$ \\
\hline Gentamycin $(10 \mu \mathrm{g})$ & 6 & $3(50 \%)$ & $2(33 \%)$ & $1(17 \%)$ \\
\hline Tetracvcline $(30 \mu \mathrm{g})$ & 4 & $4(100 \%)$ & 0 & 0 \\
\hline $\operatorname{Neomycin}(30 \mu \mathrm{g})$ & 5 & $4(80 \%)$ & $1(20 \%)$ & 0 \\
\hline Clindamycin $(2 \mu \mathrm{g})$ & 5 & $5(100 \%)$ & 0 & 0 \\
\hline Kanamycin $(30 \mu \mathrm{g})$ & 5 & $4(80 \%)$ & $1(20 \%)$ & 0 \\
\hline Penicilline(10U) & 5 & $4(80 \%)$ & $1(20 \%)$ & 0 \\
\hline Oxacillin $(1 \mu \mathrm{g})$ & 5 & $4(80 \%)$ & $1(20 \%)$ & 0 \\
\hline Enrofloxacin $(5 \mu \mathrm{g})$ & 6 & $3(50 \%)$ & $1(17 \%)$ & $2(33 \%)$ \\
\hline Cefoxitidin $(30 \mu \mathrm{g})$ & 6 & $1(16 \%)$ & $1(16 \%)$ & $4(68 \%)$ \\
\hline $\operatorname{Imipenem}(10 \mu \mathrm{g})$ & 5 & $1(20 \%)$ & $4(80 \%)$ & 0 \\
\hline Donkey milk $(0.25 \mu \mathrm{L})$ & 24 & $3(12 \%)$ & 0 & $21(88 \%)$ \\
\hline M. congesta $(0.25 \mu \mathrm{L})$ & 24 & $1(4 \%)$ & 0 & $23(\% 96)$ \\
\hline
\end{tabular}

tetracycline and clindamycin. Few of E. coli strains isolated from Urfa cheeses were not resistant to cefoxitin, imipenem, enrofloxacin used in this research (Table 1).

Our findings were similar to Momtaz et al. (2012) (29) and Stephan et al.,(2008) (30). The multidrug resistance in this study is common among E. coli isolate especially to tetracycline and ampicillin as Aslani et al.'s (2011) study (31). Tabaran et al. (2017) reported that the most often resistance was observed to cephalothin, nalidixic acid, doxycycline, tetracycline, and ampicillin (32). Paneto et al. (2007) reported that the toxigenic E. coli in cheese and raw milk were found $2 \%$ and 6 $\%(33)$.

When we compare the antibacterial activity of the essential oil of $M$. congesta and donkey milk to that of reference antibiotics, results show that the antibacterial activity of M.congesta and donkey milk is considered as significant. Our results are similar to Herken at al.'s (2012) study (16).

The antibacterial activity of donkey milk studies in $E$. coli which isolated from cheese samples, we could not find a study showing the antibacterial effect of the donkey milk.

\section{CONCLUSION}

To the best of our knowledge, this study represents the first survey of E. coli strains in Urfa cheeses produced by traditional methods in Şanliurfa, and the resistance levels of commonly used antibiotics by antibiogram test, also the antibacterial effects of donkey milk, and the essential oils of the M. congesta plant. The percentage of antibiotic resistance of the E. coli isolates studied herein are high and also the antibacterial activity of both donkey milk and M. congesta are also effectiveness. The results of this study provide knowledge about natural antibacterial sources ( $M$. congesta and donkey milk) which are growing demand for natural antibacterials for food protection and human health. Due to the potential damage of antibiotics, most direct and effective measurement for protecting the public health is the practice of preventive medicine or find alternative antibacterials.

\section{ACKNOWLEDGEMENT}

The authors wish to thank to assistant professor doctor Nilgün PAKSOY for laboratory and Grammarly helps. 


\section{REFERENCES}

1. Yangılar F, Kızılkaya PÇ. Determination of physical, chemical and microbiological properties of aromatic Ardahan cecil cheese. BEU Journal of Science. 2015; 4(2), 122-130. 2. Atasoy FA, Türkoğlu H, Özer BH. Some microbiological properties of raw milk, yogurt and fresh Urfa cheese produced and sold in Şanliurfa province. J.Agric Fac. HR.U. 2003; 7 (3-4): 77-83.

3. Coia JE. Clinical, microbiological and epidemiological aspects of Escherichia coli O157 infection.FEMS Immunology and Medical Microbiology.1998; 20: 1-9.

4. Ribeiro T, Oliveira M, Fraqueza MJ, Lauková A, Elias M, Tenreiro, R, Barreto, AS, Semedo-Lemsaddek T. Antibiotic resistance and virulence factors among enterococci isolated from Chouriço, a traditional Portuguese dry fermented sausage. J. Food Protect. 2011; 74: 465-469.

5. Vrabec M, Lovayová V, Dudriková K, Gallo J, Dudriková E. Antibiotic resistance and prevalence of Enterococcus spp. and Escherichia coli isolated from bryndza cheese. Ital. J Anim Sci. 2015; 14: 3968.

6. Aslan S, Özdemir F. Extended spectrum beta-lactamases in Escherichia coli strains isolated from homemade white cheeses prevalence and antibiotic susceptibility. World J Microbiol Biotechnol. 2008; 24: 2361-2364. 7. Bengtsson B, Unnerstad HE, Ekman T, Artursson K, Nilsson-Öst M, Waller KP. Antimicrobial susceptibility of udder pathogens from cases of acute clinical mastitis in dairy cows. Vet Microbiol. 2009; 136: 142-149.

8. Dinç G, Ata Z, Temelli S. Sığır mastitislerinden izole edilen Escherichia coli suşlarında genişlemiş spektrumlu beta-laktamaz aktivitesi ve antibiyotik dirençlilik profilinin incelenmesi. Ankara Üniv Vet Fak Derg. 2012; 59: 85-88.

9. Srinivasan V, Gillespie BE, Lewis MJ,
Nguyen LT, Headrick SI, Schukken YH, Oliver SP. Phenotypic and genotypic antimicrobial resistance patterns of Escherichia coli isolated from dairy cows with mastitis. Vet Microbiol. 2007; 124: 319-328.

10. Sumathi BR, Amitra RG, Krishnappa G. Antibiogram profile based dendogram analysis of Escherichia coli serotypes isolated from bovine mastitis. Vet World. 2008; 1: 37-39.

11. Davies J, Davies D. Origins and evolution of antibiotic resistance. Microbiol Mol Biol Rev. 2010; 74(3): 417-33.

12. Shah AA, Hasan F, Ahmet S, Hameed A. Extended -spectrum beta-lactamases (ESbLs) characterization, epidemiology and detection. Crit Rev Microbiol. 2004; 30(1): 25-32.

13. Kaya S, Baydan E. Meme içi ilaç hareketi ve meme hastalıklarının sağaltımı, Türk Vet. Hek. Derg. 1999; 11: 34-47.

14. Yıldız A. Laktasyondaki subklinik ve klinik mastitisli sütçü ineklerde lincomysin-neomycin kombinasyonuyla meme içi tedavinin etkinliği. F.Ü Sağlık Bil. Dergisi. 2003; 17(1): 65-69.

15. Kahlmeter G, Brown DF, Goldstein FW, MacGowan AP, Mouton JW, Odenholt I, Rodloff A, Soussy CJ, Steinbakk M, Soriano F, Stetsiouk O. European Committee on antimicrobial susceptibility testing (EUCAST) technical notes on antimicrobial susceptibility testing. Clin Microbiol Infect. 2006; 12: 501-503.

16. Herken EN, Çelik A, Aslan M, Aydınlık N. The constituents of Essential Oil: Antimicrobial and Antioxidant Activity of Micromeria congesta Boiss\&Hauskn.ex Boiss. from East Anatolia. J.Med Food. 2012; 15(9): 835-839.

17. Akan H, Korkut MM, Balos MM. Arat Dağı ve Çevresinde (Birecik, Şanlıurfa) Etnobotanik bir Araştırma. Sci Eng J Fırat Univ. 2008; 20: 67-81.

18. Baytop, T. Therapy with medicinal plants 
in Turkey (Past and Present). Nobel Tip publishing; 1999.

19. Şahintürk M, Öner Z. Eşek sütünün Özelliklerinin Belirlenmesi. Türkiye 12. Gida Kongresi. Trakya Üniversitesi, Edirne. 2016; 154.

20. Bauer AW, Kirby WM, Sherris JC, Turck M. Antibiotic susceptibility testing by a standardized single disk method. Amer. J. Clin. Pathol. 1966; 45: 493-496.

21. Clinical and Laboratory Standards Institute (CLSI) (2012). Performance standards for antimicrobial susceptibility testing. 32:3, CLSI, Wayne, PA.

22. Kaper JB, Nataro JP, Mobley HLT. Pathogenic Escherichia coli. Nat. Rev.Microbiol. 2004; 2: 123-140.

23. Vernozy-Rozand C, Mazuy-Cruchaudet C, Bavai C, Montet MP, Bonin V, Dernburg A, Richard Y. Growth and survival of Escherichia coli O157:H7 during the manufacture and ripening of raw goat milk lactic cheeses. Int. J. Food Microbiol. 2005; 105: 83-88.

24. Solomakos N, Govaris A, Angelidis AS, Pournaras S, Burriel AR, Kritas SK, Papageorgiou DK. Occurrence, virulence genes and antibiotic resistance of Escherichia coli O157 isolated from raw bovine, caprine and ovine milk in Greece. Food Microbiology. 2009; 26(8): 865-871.

25. Govaris A, Koidis P, Papatheodorou K. Behaviour of Escherichia coli $\mathrm{O} 157: \mathrm{H} 7$ in sour milk, cow's milk yogurt and ewe's milk yogurt. J. Dairy Res. 2002; 69: 655-660.

26. Govaris A, Papageorgiou D, Papatheodorou K. Behaviour of Escherichia coli O157:H7 during the manufacture and ripening of Feta and Telemes cheese.J. Food Prot.2002; 65: 609-615.

27. Caro I, Mateo J, Garci'a-Armesto MR. Phenotypical characteristics of Shigalike toxin Escherichia coli isolated from sheep dairy products. Lett. Appl.Microbiol. 2007;
45: 295-300.

28. Lira WM, Macedo C, Marin JM. The incidence of Shiga toxin-producing Escherichia coli in cattle with mastitis in Brazil. J. Appl. Microbiol. 2004; 97: 861-866.

29. Momtaz H, Farzan R, Rahimi E, Safarpoor Dehkordi F, Souod N. Molecular characterization of Shiga toxin-producing Escherichia coli isolated from ruminant and donkey raw milk samples and traditional dairy products in Iran. Scientific World J 2012; 1-13.

30. Stephan R, Schumacher S, Corti S, Krause G, Danuser J, Beutin L. Prevalence and characteristics of Shiga toxin-producing Escherichia coli in Swiss raw milk cheeses collected at producer level. J Dairy Sci. 2008; 91: 2561-2565.

31. Aslani MM, Alikhani MY, Zavari A, Yousefi R, Zamani AR. Characterization of enteroaggregative Escherichia coli (EAEC) clinical isolates and their antibiotic resistance pattern. Int J Infect Dis. 2011; 15: 136-139.

32. Tabaran A, Mihaiu M, Tăbăran F, Colobatiu L, Reget O, Borzan MM, Dan SD. First study on characterization of virulence and antibiotic resistance genes in verotoxigenic and enterotoxigenic $E$. coli isolated from raw milk and unpasteurized traditional cheeses in Romania. Folia Microbiologica. 2017; 62(2): 145-150.

33. Paneto BR, Schocken-Iturrino RP, Macedo C, Santo E, Marin JM. Occurrence of toxigenic Escherichia coli in raw milk cheese in Brazil. Arq Bras Med Vet Zootec. 2007; 59: 508-512. 